Hydrological Research Letters 7(3), 54-59 (2013)

Published online in J-STAGE (www.jstage.jst.go.jp/browse/hrl). doi: 10.3178/hrl.7.54

\title{
Sediment replenishment to downstream reaches below dams: implementation perspectives
}

\author{
Giyoung Ock, Tetsuya Sumi and Yasuhiro Takemon \\ Water Resources Research Center, Disaster Prevention Research Institute, Kyoto University, Japan
}

\begin{abstract}
:
Sediment replenishment below dams is an increasingly common practice in Japan to compensate sediment deficits downstream and improve habitat quality and ecological functions. We reviewed implementation methods in the context of sediment placement, and compared the design and implementation activities undertaken in the Nunome River of Japan and Trinity River of California. Nunome River was supplied with a maximum of $500 \mathrm{~m}^{3}$ of mixed sand-gravel to the stream channel from a single site through a high-flow stockpile method during a relatively small $\left(80 \mathrm{~m}^{3} / \mathrm{s}\right)$ and short (less than 4 hours) peak flow. Trinity River was supplied through an in-channel stockpile, highflow stockpile and high-flow direct injection in combination with mechanical rehabilitation with the aim of re-creating gravel bar features through fluvial processes. More (max $51,000 \mathrm{~m}^{3}$ ) and greater (gravel to boulder) sediment has been added from more than four sites along the downstream channels during a longer ( $\max 5$ days) and higher (up to $311 \mathrm{~m}^{3} / \mathrm{s}$ ) peak flow regime that are designated depending on the water year types which are determined by systematic analyses in a given year. This comparative study provides the present programs in Japan with some recommendations that will inform proper methods corresponding to riverspecific high-flow and sediment regimes.
\end{abstract}

KEYWORDS sediment replenishment; sediment management; Nunome River; Trinity River; dam impacts

\section{INTRODUCTION}

The combination of flow regulation by dam operation (i.e. loss of flow volume, magnitude and variability) and sediment deficit downstream by reservoir sedimentation can alter downstream channel morphology, such as riverbed degradation, channel incision, bank erosion and vegetation encroachment (Tsujimoto, 1999). The geomorphological changes can damage infrastructure such as bridges and embankments (Kondolf, 1997), but also simplify aquatic habitat structures and subsequently degrade ecological functions (Tanida and Takemon, 1999). In particular, loss of alluvial geomorphic features such as riffle-pool sequence and several types of riverine bars was reported not only to degrade spawning gravels of anadromous fish, such as salmonids (e.g. Oncorhynchus tshawytscha, O. kisutch and

Correspondence to: Giyoung Ock, Water Resources Research Center, Disaster Prevention Research Institute, Kyoto University, Uji, Kyoto 611-0011, Japan. Present address: Institute of Urban and Regional Development, University of California Berkeley, CA 94720, USA. E-mail: giyoung.ock@gmail.com (C2013, Japan Society of Hydrology and Water Resources.
O. mykiss) (Ligon et al., 1995) and Ayu (Plecoglossus altivelis) (Takemon, 1997), but also to elongate transport distance of reservoir plankton and disturb trophic balance in the riverine foodweb system (Ock and Takemon, 2010).

In order to address the sediment deficit downstream and to mitigate the morphological changes derived by the sediment starved waters, comprehensive sediment management strategies have been developed in Japan and worldwide, such as 'sediment replenishment' (Wheaton et al., 2004; Kantoush et al., 2010), 'sediment bypassing tunnel' (Sumi et al., 2004), 'flood mitigation dam' (Sumi, 2008) and 'dam removal' (Stanley and Doyle, 2003). Among the mitigation measures, sediment replenishment, which is the method whereby bedload-sized sediment is artificially added to the river channel below dams, is an increasingly common practice in Japanese rivers particularly on the east coast connecting the Pacific Ocean.

Sediment replenishment, otherwise known as sediment augmentation, has been undertaken below at least 15 dams in Japan (Okano et al., 2004), including the Kizu River basin system such as the Nabari River below Muro Dam (since 2006), Hinachi Dam (since 2008) and Shorenji Dam (since 2009), and Nunome River below Nunome Dam (since 2004) (Kantoush et al., 2010). However, these applications still require a systematical development in the stages of planning and implementation, both of which are in concert with specific objectives and local hydrophysical restrictions in the basin, reservoir and river. In particular, predicting flushing flows (magnitude, frequency and timing), determining quantity (amount added) and quality (grain size and source materials) of coarse sediment, and selecting an effective implementation technique for adding and transporting sediment in the fields are key factors in achieving a successful result in ecological river management and restoration.

In northern California, US, gravel augmentation has been widely used in more than 18 regulated rivers with the aim of constructing riffles for salmon spawning (Kondolf and Matthews, 1993; Kondolf and Minear, 2004). Among them, the Trinity River below Lewiston Dam was first undertaken in 1976 and the augmentations have continued to this day. The Trinity River Restoration Program (TRRP) has been at the forefront of efforts to restore bed-load supply and transport in the regulated reaches below the dam in the United States (Gaeuman, 2012), developing systematic sediment management techniques and accumulating empirical data that covers various aspects of physical and ecological researches.

In the present study, we compare the sediment replenishment activities undertaken in Nunome River, Japan 
and Trinity River, US, in the context of main objectives, planning and implementation, with the aim of providing practical recommendations for improving effectiveness of sediment replenishment projects that are currently applied or planned.

\section{SEDIMENT REPLENISHMENT METHODS DEPENDING ON IMPLEMENTATION TYPES}

Sediment replenishment to rivers below dams is called 'Dosha-Kagen' in Japan and simply 'gravel augmentation' in United States when gravel- and cobble-sized sediments are input directly or indirectly to stream channels. Compared with other sediment management strategies, this approach is likely to be unsustainable owing to periodical implementations to make up for the sediment deficit caused by the dam. However, this approach has been widely applied in Japanese rivers as an important component of the efforts because of its relative merits such as immediate benefits, particularly to restore the downstream habitat primarily with regards to improved fish spawning habitat (Wheaton et al., 2004).

Although a considerable amount of researches have addressed the sediment replenishment (mainly spawning gravel quality and quantity), those focusing on implementation technique itself are scarce. Among increasing issues in relation to sediment replenishment, a number of restoration projects described the difficulty of implementation activity (Harvey et al., 2005). Several implementation techniques have evolved in response to available spaces, release flow regimes, costs and accessibility as well as primary objectives. Coarse sediments can be added to channels by following different injection types, and Kondolf and Minear (2010) proposed three different methods for sediment placement with their advantages and weaknesses, and McBain and Trush (2004) provided schematic concepts on the classification.

Firstly, In-channel bed stockpile is a relatively old method which started from 1970, but even now it is widely used for supplementation of riffles or pool tails. This approach places directly spawning gravels within the low flow channel to provide immediate usable habitat features. This method, however, involves in-channel work at low flows, which may increase turbidity downstream. Sediment that is largely immobile under low flow would start to transport downstream when the flow exceeds bed mobility threshold. Secondly, the High-flow stockpile method places gravel along the channel bank margin to be distributed downstream by high flows. This method assumes that the river itself will transport sediment and reshape the channel during high flow events. Where peak flows in stream channel have a short duration and high magnitude, it would be applicable as an efficient method. It is a common method currently applied in Japan. This approach can add relatively large amounts of gravel at relatively low cost, but is limited to volume piled and the number of suitable sites. Thirdly, the Point bar stockpile method introduces coarse sediment to augment or create a point bar. The augmentation is accomplished using site-specific low flow and bankfull channel dimensions of the reaches. The volume of coarse sediment introduced can be exaggerated because some of it
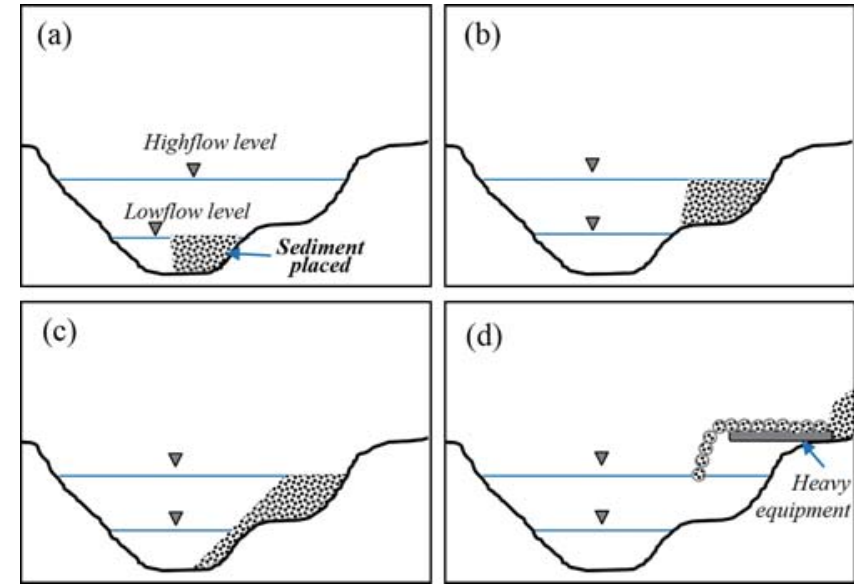

(d)

Figure 1. Sediment replenishment methods according to sediment placement or injection types. (a) In-channel bed stockpile, (b) High-flow stockpile, (c) Point bar stockpile and (d) High-flow direct injection

can be routed downstream during high-flow events. However, the coarse sediment stockpiled at the inside bend in a meandering channel would be limited to erosion and transport downstream during high flows. Additionally, Gaeuman (2013) proposed the process of High-flow direct injection, which directly introduces gravel to the river channel during a high flow event using heavy equipment such as a conveyor belt. While the high-flow stockpile can be quickly exhausted in a large flow, this approach can allow new sediment to replace the material already transported. Also, an advantage of this method over high-flow stockpile is that a larger volume and coarser gravel can be introduced during the course of a flood. Figure 1 differentiates the mechanisms of the methods in relation to flow regime and sediment placement, and Table I summarizes the advantages and weaknesses of the four approaches.

\section{SEDIMENT REPLENISHMENT IN THE NUNOME RIVER}

The Nunome Dam which was built in 1994 in the Nunome River, a tributary of the Kizu River in Nara prefecture, Japan $\left(34^{\circ} 42^{\prime} \mathrm{N}, 135^{\circ} 58^{\prime} \mathrm{E}\right)$, was planned to set sedimentation capacity to 100 years $\left(1,900,000 \mathrm{~m}^{3}\right)$, but sedimentation in the reservoir progressed faster than that of the original plan, and the sedimentation rate in 2006 already reached 13 percent $\left(243,000 \mathrm{~m}^{3}\right)$ of the planned sedimentation (Kantoush et al., 2010). The rate would have accelerated unless appropriate sediment management in the reservoir and upstream basin had been employed. In the Nunome Dam, sediment replenishment began in 2004, and then a total of $2,585 \mathrm{~m}^{3}$ of coarse sediment was replenished almost annually to Nunome River through to 2009.

The sediment for replenishment was mechanically excavated at the check dam located at the upstream end of the reservoir, moved to the downstream river below the dam by dump truck, and then deposited on the right bank $300 \mathrm{~m}$ below the Nunome Dam. The placed sediment consists 
Table I. Classification of sediment replenishment according to augmentation techniques

\begin{tabular}{|c|c|c|}
\hline Types & Advantages & Weaknesses \\
\hline In-channel bed stockpile & $\begin{array}{l}\text { - immediately usable habitat features such as } \\
\text { spawning riffles are expected } \\
\text { - in-channel riffles can be supplemented or } \\
\text { reconstructed in a given channel } \\
\text { - potential for transport is expected using a relatively } \\
\text { small release flow }\end{array}$ & $\begin{array}{l}\text { - in-channel construction is required } \\
\text { - turbidity during addition would be an issue } \\
\text { - constructed features may remain temporally only } \\
\text { until the next flood event } \\
\text { - risk that existing habitats may be degraded by } \\
\text { erosion during the next flood } \\
\text { - sediment transport is dependent on the next flood }\end{array}$ \\
\hline High-flow stockpile & $\begin{array}{l}\text { - coarse sediment can be routed when channel } \\
\text { transport capacity is high } \\
\text { - large volumes and sizes of sediment can be added } \\
\text { at a relatively low cost } \\
\text { - little in-channel construction is required } \\
\text { - more functional channel morphology is expected } \\
\text { than the in-channel method } \\
\text { - peak flows with a short duration and high magnitude } \\
\text { would be applicable }\end{array}$ & $\begin{array}{l}\text { - number of addition sites are limited } \\
\text { - timing for implementation and amount of sediment } \\
\text { added are limited to high-flow events } \\
\text { - coarse sediment supply may be quickly exhausted } \\
\text { during a short high flow }\end{array}$ \\
\hline Point bar stockpile & $\begin{array}{l}\text { - in-channel features can be created within long pool } \\
\text { reaches where spawning habitats are currently } \\
\text { limited } \\
\text { - alternate bar morphology that potentially has a high } \\
\text { habitat quality can be induced at low-flow channels }\end{array}$ & $\begin{array}{l}\text { - a large volume of coarse sediment is required } \\
\text { - it is difficult to locate project site } \\
\text { - coarse sediment that is placed at inside channel } \\
\text { meander would be limited to erosion and transport } \\
\text { downstream during high flow }\end{array}$ \\
\hline High-flow direct injection & $\begin{array}{l}\text { - coarser sediment can be introduced at thalweg line } \\
\text { during high transport capacity } \\
\text { - larger volumes of gravel can be added during longer } \\
\text { peak flows } \\
\text { - longer transport and deposition of added sediment } \\
\text { are expected by downstream fluvial processes }\end{array}$ & $\begin{array}{l}\text { - working conditions in field would be hazardous } \\
\text { - amount of sediment is dependent on high flow } \\
\text { releases and peak duration } \\
\text { - sediment should be immediately available for } \\
\text { placement }\end{array}$ \\
\hline
\end{tabular}

Data were partially derived from Kondolf and Minear (2004), McBain and Trush (2004) and Harvey et al. (2005)

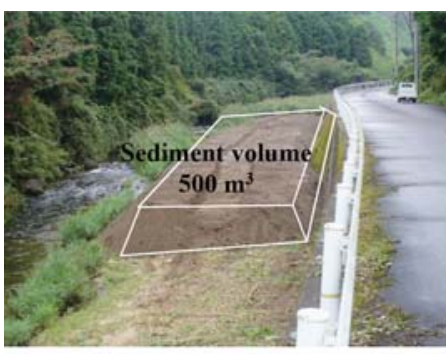

(a) Before flood (sediment placed)

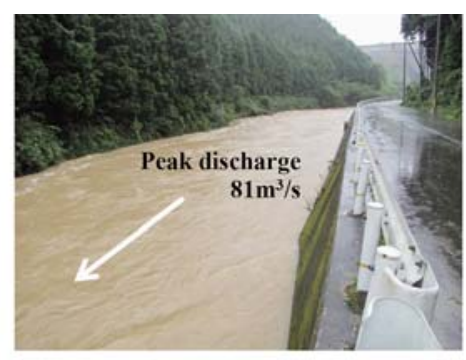

(b) During flood (Oct $8^{\text {th }}$ 2009) (sediment eroded)

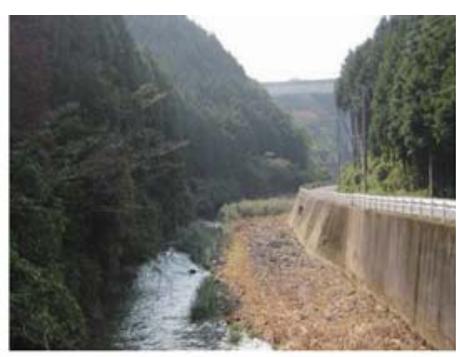

(c) After flood (Oct 14 $4^{\text {th }} 2009$ ) (sediment transported downstream)

Figure 2. High-flow stockpile process in the Nunome River, Japan

mainly of sand and gravel with $0.38 \mathrm{~mm}$ median size $\left(d_{50}\right)$ ranging from 0.075 to $19 \mathrm{~mm}$. The volume of replenished sediment in a single implementation varied from 80 to $500 \mathrm{~m}^{3}$, which depended on magnitude and duration of flushing flow. Based on the event in October $2009,500 \mathrm{~m}^{3}$ of coarse sediment was transported downstream by an $81 \mathrm{~m}^{3} / \mathrm{s}$ peak flow for 4 hours as shown in Figure 2 .

Monitoring researches on geomorphological changes such as sand bar formation below implementation site and bed material variation along channel were described in Sumi and Kantoush (2010) and Kantoush et al. (2010). Longitudinal variation of particulate organic matter dynamics and benthos communities was discussed in Ock (2010).

\section{GRAVEL AUGMENTATION IN THE TRINITY RIVER}

The Trinity River located in northwest California is the largest tributary to the Klamath River. The TRRP has its primary management reach between Lewiston Dam $\left(40^{\circ} 43^{\prime} \mathrm{N}, 122^{\circ} 47^{\prime} \mathrm{W}\right)$ and the North Fork Trinity River (Figure 3), as this reach of approximately $64 \mathrm{~km}$ has had its aquatic and terrestrial habitats severely changed by the Trinity River Division Project which diverted about 90 percent of the river's water to the Sacramento River basin in the Central Valley. Subsequent reduction of both flow and sediment downstream resulted in the loss or degradation 
of salmon habitats and caused naturally produced salmon populations to decline by up to 60 to 96 percent depending on the species. Although considerable restoration efforts were made through to the year 2000 focused on 'mechanical activities' such as dredging, channelization, artificial spawning beds and vegetation removal, these efforts have been evaluated to have been ineffective in restoring the naturally produced salmon population levels. Thus, the restoration strategies were completely changed in the year 2000 , to induce 'natural processes' morphologically leading to building and maintaining required salmon habitat (ROD, 2000). 'Coarse sediment replenishment' was a focus of the management actions in TRRP.

TRRP determines five water year types based solely on Trinity Reservoir inflow. The probability of these water year types occurring is based on historical data from the previous eight decades. Total allocation ranges from $1,005 \mathrm{mcm}$ (million cubic meters) of the 'extremely wet year' to $455 \mathrm{mcm}$ in the 'critically dry year'. Based on average inflow to Trinity Reservoir, allocation to Trinity River represents 43 percent of total inflow into Trinity Reservoir (Table IIa). Once the water year type is designated and the allocation downstream is established, the discharge pattern proposed is outlined in the Trinity River Flow Evaluation (USFWS and HVT, 1999). Peak discharge is to range from $311 \mathrm{cms}$ (cubic meter per second) to $42 \mathrm{cms}$ corresponding to the water year type (Table IIb). Release patterns for each water year class were developed to accomplish a variety of fishery and geomorphological objectives such as water temperature requirements to provide optimal holding/spawning/survival temperature for adults, smolts and fry stages, ramping to

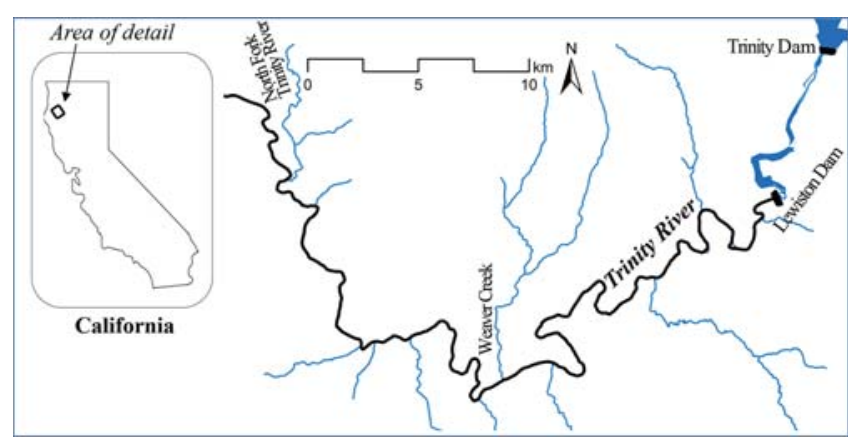

Figure 3. Location of the Trinity River below the Lewiston and the Trinity Dams in northwest California, US peak flow and reducing travel time of outmigrating smolts and sediment transport to create or maintain bar morphology.

In order to address the sediment deficit downstream caused by both upstream dams (Trinity and Lewiston Dam), TRRP has added gravel-size sediments (over $8 \mathrm{~mm}$ ) that is appropriate for a spawning bed. The amount of gravel introduced into the river is based on scientific analyses and calculation of a gravel budget for the river (USFWS and HVT, 1999; Gaeuman, 2008; Gaeuman and Krause, 2011), and is designated up to 51,000 tons depending on the five water year types as described in Table IIb. Augmentation has been implemented by the High-flow direct injection and the High-flow stockpile by placement. The added gravels are generally delivered from 'on-site' sources in the floodplain where terraces are mechanically lowered and riparian berms are removed in order to improve channel dynamics in combination with gravel augmentation.

Also, the grain size of sediment added as well as the volume should be estimated from comparison of pre- and post-dam topography. The sediment transport capacity of the river below dams is reduced after dam construction, thus it would rarely be appropriate to add the pre-dam sediment load to the channel below the dam. Because dams typically reduce not only the volume of sediment transported but also the gravel sizes able to be transported, the size distribution of augmented gravel should typically be smaller than the pre-dam load. In addition, as many riverbeds have coarsened below dams, the added gravel is significantly smaller than the existing bed material size to increase availability of spawning-sized gravel and sediment mobile under the current flow regime. In TRRP, the gravel added to river is greater than $15 \mathrm{~mm}$ in size after sieving to remove fine sediments. It consists mainly of large cobbles ranging in size between 25 to $102 \mathrm{~mm}$ and able to become mobile under anticipated flow regimes and be suitable to support spawning (Gaeuman, 2008).

In selecting the number of sites and locations where gravel augmentations are implemented, the sediment delivery from tributaries and sediment transport capacity below injection site were considered as well as accessibility and effectiveness for field work. Within the TRRP project area of 40 miles in length, a total of four locations were designated for high flow coarse sediment augmentation, because the downstream channel below the region shows the natural geomorphological process by sediment introduction and flow variation from several tributaries.

Table II. Systematic criteria of the five water year types and corresponding peak flow and sediment amount in a given year type in the Trinity River Restoration Program

\begin{tabular}{|c|c|c|c|c|c|c|c|}
\hline \multirow[b]{2}{*}{ Water year type } & \multicolumn{4}{|c|}{ (a) Downstream release depending on reservoir inflow } & \multicolumn{3}{|c|}{ (b) Peak flow and sediment augmented } \\
\hline & $\begin{array}{l}\text { Reservoir } \\
\text { inflow } \\
(\mathrm{mcm})\end{array}$ & $\begin{array}{l}\text { Downstream } \\
\text { allocation } \\
(\mathrm{mcm})\end{array}$ & $\begin{array}{l}\text { Ratio inflow } \\
\text { to allocation }\end{array}$ & $\begin{array}{l}\text { Probability } \\
\text { of occurrence }\end{array}$ & $\begin{array}{l}\text { Peak flow } \\
\text { released } \\
(\mathrm{cms})\end{array}$ & $\begin{array}{l}\text { Peak flow } \\
\text { duration } \\
\text { (days) }\end{array}$ & $\begin{array}{c}\text { Volume of } \\
\text { sediment } \\
\text { augmented }\left(\mathrm{m}^{3}\right)\end{array}$ \\
\hline Extremely wet & $>2,467$ & 1,005 & $35 \%$ & 0.12 & 311 & 5 & $23,701-51,224$ \\
\hline Wet & $1,665-2,466$ & 865 & $44 \%$ & 0.28 & 241 & 5 & $7,645-13,761$ \\
\hline Normal & $1,264-1,664$ & 798 & $58 \%$ & 0.20 & 170 & 5 & $1,376-1,682$ \\
\hline Dry & $801-1,263$ & 559 & $56 \%$ & 0.28 & 127 & 5 & $115-191$ \\
\hline Critically dry & $<801$ & 455 & $81 \%$ & 0.12 & 42 & 36 & 0 \\
\hline average & & 733 & $43 \%$ & & & & \\
\hline
\end{tabular}

'mcm' and 'cms' indicate million cubic meters and cubic meters per second, respectively. 


\section{SUMMARY AND RECOMMENDATIONS}

Table III summarized the sediment replenishment differences between Nunome River and Trinity River including the purposes, implementation methods used and flushing flow properties and augmented sediment properties. Based on the findings from the gravel augmentation project in the Trinity River, some recommendations are presented for improvement of the Nunome River restoration project.

There is a strong requirement to use an appropriate implementation method to respond to project purpose, channel transport capacity, cost effectiveness and accessibility. TRRP has developed the methods based on local field restrictions, and has adopted the high-flow direct injection and high-flow stockpile. In some vegetated riparian areas, riparian berms were removed in combination with gravel augmentation. The Nunome River replenishment project has mainly used the high-flow stockpile method during only a limited peak duration caused by intensive rainfall and typhoon. Although the method is effective for large amount of sediment stockpiled to be transported downstream in a single event, the downstream length for added sediment to be transported and deposited is likely not greater than the high-flow direct injection method. Major deposition was actually found at just $300 \mathrm{~m}$ below the implementation site below Nunome Dam (Kantoush et al., 2010). If we expected a much longer transport distance of replenished sediment, the high-flow injection would be effective. The method is able to add sediment directly to the thalweg line and enables a greater amount of gravel supplied downstream than highflow stockpile when a longer peak duration is allowed. In addition, in the case where the riparian berms occupied by dense bamboo in the Kizu River system were designedly restored into a point bar, the bank rehabilitation in combination with removal of the riparian berm would promote the fluvial geomorphologic processes derived by sediment replenishment.

In the Nunome River, the largest amount of coarse sediment replenished in a single event was recorded as 500 tons on August and October of 2009. The grain size consisted mainly of mixed sand and gravels of size less than $19 \mathrm{~mm}$. The frequency and amount of the sediment replenishment has been dependent on flushing flow released downstream during the flooding season in July to October. To date, the magnitude of the flushing flow was likely determined for the purpose of mainly flood control to drawdown the reservoir water level. On the one side, the replenishment activities might be effective in the aspects of riverbed degradation and detachment of attached algae, and sand bar formation at the meandering point. However, on the other side, the sand deposited along the channel could be problematic in terms of habitat condition by burying spawning gravel and filling rearing pools. Also, the amount and grain size of sediment replenished is likely to be insufficient to create an in-channel bar system. Thus, if we design to restore the bar features that are available for spawning beds, and to transport the coarse sediment much farther downstream, the much higher magnitude of the flushing flow and longer duration time of the peak flow will be required.

In the planning stage for determining the spatial boundary of the research project, the possible sediment compensation capacity from tributaries should be considered. As described before, TRRP sets up the limit boundary for gravel augmentation projects from just the downstream

Table III. Comparative analyses of sediment replenishment activities between Nunome River and Trinity River

\begin{tabular}{|c|c|c|c|}
\hline & & Nunome River & Trinity River \\
\hline Year started & & 2004 & 1972 \\
\hline Organization & & Japan Water Agency & US Bureau of Reclamation \\
\hline \multirow[t]{2}{*}{ Purposes } & Physical objectives & to protect riverbed degradation & $\begin{array}{l}\text { to induce natural fluvial process for gravel } \\
\text { bar formation }\end{array}$ \\
\hline & Ecological objectives & to detach attached algae & to restore salmon habitat structure \\
\hline \multicolumn{2}{|l|}{ Implementation method } & High-flow stockpile & $\begin{array}{l}\text { In-channel stockpile, High-flow stockpile, } \\
\text { High-flow injection }\end{array}$ \\
\hline \multirow{4}{*}{ High flow regime } & Peak discharge & by peak control by the dam & $\begin{array}{l}\text { by the water year type determined based } \\
\text { on reservoir inflow within a given year }\end{array}$ \\
\hline & Peak magnitude & approx. $80 \mathrm{~m}^{3} / \mathrm{s}$ & $\begin{array}{l}\text { by the water year type ranging from } 42 \text { to } \\
311 \mathrm{~m}^{3} / \mathrm{s}\end{array}$ \\
\hline & Frequency & once or twice a year in summer & once a year in spring \\
\hline & Peak duration & $2-4$ hours & over 5 days \\
\hline \multirow{4}{*}{ Sediment added } & $\begin{array}{l}\text { Source of excavated } \\
\text { sediment }\end{array}$ & check dam located at end of reservoir & $\begin{array}{l}\text { on the channel derived from mechanical } \\
\text { floodplain rehabilitation }\end{array}$ \\
\hline & Number of sites & a single site just below dam & four sites along downstream channels \\
\hline & $\begin{array}{l}\text { Sediment volume } \\
\text { added per year }\end{array}$ & by the peak discharge $\left(\max 500 \mathrm{~m}^{3}\right)$ & by the water year type $\left(\max 51,224 \mathrm{~m}^{3}\right)$ \\
\hline & Grain size & mixed sand and gravel $(0.075-19 \mathrm{~mm})$ & mixed gravel and boulder (15-102 mm) \\
\hline
\end{tabular}


site to the upper half river below the dam, because from the lower half, sediment deficit seems to be sufficiently compensated through tributary introduction. The main stream of Kizu River, fortunately, has no large dam built. The Nunome Dam and the other four dams were constructed in the tributary basins. Therefore, the coarse sediment load from tributaries below the confluence of Nunome River should be one of the determinants for planning the amount of sediment added and implementation sites.

\section{ACKNOWLEDGEMENT}

We are grateful to Trinity River Restoration Program and Dr. Matt Kondolf for providing TRRP research reports. Two anonymous reviewers provided careful reading and valuable comments on this paper. This research was partially supported by the institutional program for young researchers overseas study in Disaster Prevention Research Institute of Kyoto University and by a research project titled "Development of river-bed management techniques for river environments" financed by the Japanese Ministry of Land, Infrastructure, Transport and Tourism.

\section{REFERENCES}

Gaeuman D. 2008. Recommended quantities and gradation for long-term coarse sediment augmentation downstream from Lewiston Dam. TRRP Technical Monograph: TM-TRRP2008-2. Weavervill, CA.

Gaeuman D. 2012. Mitigating downstream effects of dams. In Gravel-Bed Rivers: Processes, Tools, Environments. Church M, Roy AG, Biron PM (eds). John Wiley \& Sons, Ltd. West Sussex, UK; 182-189.

Gaeuman D, Krause A. 2011. 2010 Bed material sediment budget update, Trinity River, Lewiston Dam to Douglas City, California. TRRP Technical Report: TR-TRRP-2011-2. Weavervill, CA.

Harvey B, McBain S, Reiser D, Rempel L, Sklar LS, Lave R. 2005. Key uncertainties in gravel augmentation: geomorphological and biological research needs for effective river restoration. CALFED Science Program and Ecosystem Restoration Program Gravel Augmentation Panel Report.

Kantoush SA, Sumi T, Kubota A. 2010. Geomorphic response of rivers below dams by sediment replenishment technique. Proceedings of the River Flow 2010 Conference, Braunschweig, Germany; 1155-1163.

Kondolf GM. 1997. Hungry water: effects of dams and gravel mining on river channels. Environmental Management 21: 533-551. doi: 10.1007/s002679900048.

Kondolf GM, Matthews WVG. 1993. Management of coarse sediment in regulated rivers of California. Report No. 80. University of California Water Resources Center, Davis, California.

Kondolf GM, Minear JT. 2004. Coarse sediment augmentation on the Trinity River below Lewiston Dam: Geomorphic perspectives and review of past projects. Report to Trinity
River Restoration Program, Weaverville, CA.

Ligon FK, Dietrich WE, Trush WJ. 1995. Downstream ecological effects of dams. BioScience 45: 183-192. doi: 10.2307/ 1312557.

McBain and Trush. 2004. Coarse sediment management plan for the lower Tuolumne River Final Report. Prepared for the Tuolumne River Advisory Committee.

Ock G. 2010. Particulate Organic Matter Dynamics in the Downstream of Dam Reservoirs: Roles of Channel Geomorphology and Responses of Benthos Communities. Ph.D Thesis of the Graduate School of Engineering. Kyoto University, Kyoto, Japan.

Ock G, Takemon Y. 2010. Estimation of transport distance of fine particulate organic matter in relation to channel morphology in tailwaters of the Lake Biwa and reservoir dams. Landscape and Ecological Engineering 6: 161-169. doi: 10.1007/ s11355-009-0099-y.

Okano M, Kikui M, Ishida H, Tetsuya S. 2004. Reservoir sedimentation management by coarse sediment replenishment below dams. Proceedings of the 9th International Symposium on River Sedimentation, Yichang, China; 1070-1078.

ROD. 2000. Record of Decision: Trinity River Mainstem Fishery Restoration Final EIS/EIR., US Department of the Interior, Washington DC.

Stanley EH, Doyle MW. 2003. Trading off: the ecological effects of dam removal. Frontiers in Ecology and the Environment 1: 15-22. doi: 10.1890/1540-9295(2003)001 [0015:TOTEEO]2.0.CO;2.

Sumi T. 2008. Designing and operating of flood retention "Dry Dams" in Japan and USA. Proceedings of the 8th International Conference on Hydro-Science and Engineering (ICHE-2008) 8-12.09. Nagoya, Japan.

Sumi T, Kantoush SA. 2010. Integrated Management of Reservoir Sediment Routing by Flushing, Replenishing, and Bypassing Sediments in Japanese River Basins. Proceedings of the 8th International Symposium on Ecohydraulics, Seoul, Korea; 831-838.

Sumi T, Okano M, Takata Y. 2004. Reservoir sedimentation management with bypass tunnels in Japan. Proceedings of the 9th International Symposium on River Sedimentation, Yichang, China; 1036-1043.

Takemon Y. 1997. Management of biodiversity in aquatic ecosystems: dynamic aspects of habitat complexity in stream ecosystems. Biodiversity. Springer: 259-275. doi: 10.1007/ 978-1-4612-1906-4 16.

Tanida K, Takemon Y. $1 \overline{9} 99$. Effects of dams on benthic animals in streams and rivers. Ecology and Civil Engineering 2: 153164 (In Japanese with English abstract). doi: 10.3825/ ece.2.153.

Tsujimoto T. 1999. Effects of dams on physical environment of rivers: from the aspects of river engineering and hydraulics. Ecology and Civil Engineering 2: 103-112 (in Japanese with English Abstract). doi: 10.3825/ece.2.103.

USFWS (US Fish and Wildlife Service), HVT (Hoopa Valley Tribe). 1999. Trinity River Flow Evaluation Study - Final Report. Report to the US Department of the Interior. Washington D.C.

Wheaton JM, Pasternack GB, Merz JE. 2004. Spawning habitat rehabilitation-I. Conceptual approach and methods. International Journal of River Basin Management 2: 3-20. doi: 10.1080/15715124.2004.9635218. 